\title{
Nowcasting income inequality in the context of the Fourth Industrial Revolution
}

\section{Olha Kuzmenko,}

Doctor, Professor, Head of Economic Cybernetics Department, Sumy State University. Head of Scientific and Educational Center for Business Analytics, Ukraine

\section{Victoria Roienko}

\author{
Ph.D, Associated Professor, Sumy State University, Ukraine
}

(C) The Authors, 2017. This article is published with open access at ARMG Publishing.

\begin{abstract}
The Fourth Industrial Revolution is opening up huge growth prospects for the world economy, while at the same time appearing new or worsening existing problems, one of which is income inequality. The issue of inequality has significant socio-economic and geopolitical importance worldwide since the substantial social and property stratification of the population leads to exacerbation of local, national and even international confrontations in society. This article examines the main technological and socio-economic drivers related to the Fourth Industrial Revolution (Industry 4.0) on income inequality in developed countries (France, Germany, Italy, Spain, UK). Based on recognition of trend and the cyclical component of the dynamics of income inequality and Industry 4.0indicators and using Google search data the authors nowcast the level of Gini coefficient on 15 years ahead.
\end{abstract}

Keywords: income inequality, the Fourth Industrial Revolution, nowcasting, Gini index.

JEL Classification: D6, O33, E27, C21

\section{Introduction}

The world is entering the Fourth Industrial Revolution. Storage capacity and data growth, appearance of intelligent robots, convergation of web, cloud and mobile platforms, increasing networked communication - it refers to the dramatic changes in business and production process. Concurrent to the digital revolution, there are set of socio-economic, demographic, financial drivers of change which is reinforcing one another and leading to such main consequences as: 1) decrease in the number of highly repetitive low-skill jobs and routine medium-skill job. In this context, artificial intelligence will initially affect clerical work, sales, customer services. The World Bank estimates that increasing automation will put $57 \%$ of the jobs in the 35 countries in OECD at risk, including $47 \%$ of US jobs and $77 \%$ of the jobs in China; 2) efficiency improvement of existing jobs and increase in demand for customized human work; 3 ) go up the magnitude and probability of risks related to cybersecurity; 4) raise income inequality - the return to skills is likely to benefit those who are rich and lower-paid workers suffer from income underperformance. So, while the Fourth Industrial Revolution is enabling extraordinary levels of innovation and knowledge, it is also contributing to a widening inequality gap.

Global income inequality stands at very high levels, whereby the richest $8 \%$ of the world's population earn half of the world's total income, while the remaining $92 \%$ of people are left with the other half. Income inequality has been increasing in many countries all over the world owing to a range of factors, including: inadequately regulated financial integration, trade liberalization processes, institutional and regulatory reforms that have increased competition in product and factor markets and, of course, technological change, which has favored high-skilled workers.

Therefore, it raises the question of necessity to carry out research and develop economical mathematical models, which could make it possible to identify the factors of income inequality variation influenced by industry 4.0 and find out the mechanism of its regulation on the basis of correlation analysis, principal components method, non-linear regression, harmonic and decomposition analysis; calculate values of nowcasting trends of income inequality on the base of Google Trends. 


\section{Literature review}

A vast literature exists that aims to identify the main determinants of income distribution and their impact on global and national levels. But there is no consensus among experts on drivers of increasing income inequality.

The International Monetary Fund (IMF(2007)) analyzes the effects of globalization, changes in technology, and labour market institutions on income distribution. Citing evidence from IMF (2007) and using data from 51 countries over the period 1981-2003, Papageorgiou et al. (2008) [24] outline main control variables (technological development, access to education, sectoral share of employment, domestic financial development) that can determine inequality changes in developing and high income countries. Authors have proved that technological progress measured by the share of ICT capital in the total capital stock significantly increase inequality. However, they also highlight that the disequalizing effect of technological progress is stronger in Asia than on average weaker in Latin America.

According to International Labour Organization [28], key determinants in wage shares and assessing relative contributions are technological change, financialization, globalization and welfare state retrenchment. Different proxies for measuring technological change in developing (the capital labor ratio and ICT services) and advanced economies (share of agriculture and industry in GDP) were used. Anastasia Guscina (2006) [18] has examined the impact of technology, openness, and employment protection policies on the labor share in national income over the period 1960-2000. The author argues that during the preglobalization/pre-IT period the technological progress is labor-augmenting thereby inequality decreases. However, during the postglobalization/post-IT revolution era technological progress is capital augmenting and inequality increases.

Most scientists claim that technological development influences on the distribution of income and increases gap between skilled and unskilled labor. The latter notion can be traced back to Krueger (1993) [21] who argued that employees who directly use computers at work earn a 10 to 15 percent higher wage rate. These results were obtained by analyzing the data between 1984 and 1989. Based on this view, Berman, Bound, Machin Krusell, et al. (2000) [22], Acemoglu (2002) [1], Card and DiNardo (2002), Hornstein et al. (2005) [19], Violante (2012) [31], Berman et al. $(1994 ; 1998)$ [5, 6] placed that technological change is inherently skill-biased, attributing the growth in income inequality to technology shocks. Technological changes can disproportionately raise the demand for capital labor removing many jobs through automation or computerization (Card and Dinardo, 2002) [10].

An alternative view (Goldin and Katz, 2008) [17] is that wage inequality is explained mainly by changes in education, not by shifts in technology, immigration, globalization or so on. For instance, the increase in the college wage premium explains about 60 to $70 \%$ of the rise in the wages distribution among U.S. citizens between 1980 and 2005. The light of this view, Kevin J. Lansing and Agnieszka Markiewicz (2012) [23] developed a general-equilibrium model skill-biased technological change as a diffusion process that transfers the parameters of the representative firm's constant elasticity of substitution production function in a way that approximates observed movements in the shares of wage and non-wage income.

Technological shifts affect the functional distribution of income by raising the labor productivity and returns on capital. Borghans and er Weel $(2002,2004)$ [8] argue that the maximum level of wage inequality depends on the distribution of productivity of workers within and between groups and also conduct the differences in initial wage inequality between skilled and unskilled workers even in developed countries (USA, Germany). Technological development, in both developed and developing countries, increases the premium on skills and tends to substitute away from low-skill inputs, thereby exacerbating inequality in income (Birdsall, 2005) [7].

Despite growing interest and theoretical debate of correlation between income inequality and technological changes, the empirical research is still limited. This paper aims to analyze literature concerning these problem, identify main drivers of the Fourth Industrial Revolution and its impact on the dynamics of income distribution in developed European countries and forecast future trends.

\section{Methodology}

The empirical procedure of this article to analyze the main questions is as follows: first, an identification of the relevant indicators of evaluation of technological and socio-economic changes resulting from the Industry 4.0 through using significant influence on the income inequality using correlation. Second, authors adjust relevant factors (technological, socio-economic) in the context of impact on income inequality using high frequently data. Lastly, researches nowcast the level of income inequality adjusted with Fourth Industrial 
Revolution in developed countries with the application of mathematical methods by decomposition of the considered time series filtering trend and seasonal (cyclic) components.

There are two obvious types of data required to test the hypothesis of correlation between the Fourth Industrial Revolution and income inequality, thereafter predict the ratio of income inequality adjusted with Industry 4.0 growth. Firstly, authors decide to assess the income inequality based on Gini index (World Bank Database) and secondly, they look at measures of the Fourth Industrial Revolution, in the context of technological changes (enterprises using software solutions; e-government activities of individuals via websites; individuals using the Internet for ordering goods or services; percent of individuals aged 16 to 74; share of enterprises' turnover on e-commerce; estimated yearly shipments of multipurpose industrial robots in selected countries) and socio-economic shifts (venture capital investments of GDP; employed ICT specialists; human resources in science and technology. The hypothesis is tested on a panel data of five developed European countries (France, Germany, Italy, Spain, UK) over the period 2007-2017.

\section{Results of research}

This paper is aimed at determining main forces of income inequality in developed countries in terms of exponential growth of the Fourth Industrial Revolution and nowcasting these trends.

Firstly, in the context of each country (France, Germany, Italy, Spain, UK) authors have defined a set of technological and socio-economic indicators that carry on significant influence on the income inequality through using correlation analysis and principal components method. The results of the implementation of this stage of modeling and nowcasting trends of income inequality variation influenced by Industry 4.0 are present in Table 1. Choosing relevant impacts on income inequality is based on the pair correlation coefficients, the value of which indicates statistically confirmed weak, average or close relationship.

Table 1. Results of correlation between technological and socio-economic indicators and income inequality

\begin{tabular}{|c|c|c|c|c|c|}
\hline \multirow{2}{*}{ Indicators } & \multicolumn{5}{|c|}{ Gini coefficient } \\
\hline & France & Germany & Italy & Spain & UK \\
\hline \multicolumn{6}{|c|}{ Technological indicators } \\
\hline Enterprises using software solutions & 0.686 & 0.413 & $\mathbf{0 . 7 3 8}$ & $\mathbf{0 . 9 3 4}$ & -0.379 \\
\hline E-government activities of individuals via websites & 0.294 & -0.105 & 0.276 & 0.959 & -0.087 \\
\hline Individuals using the Internet for ordering goods or services & 0.441 & 0.079 & 0.636 & 0.922 & -0.531 \\
\hline Share of enterprises' turnover on e-commerce & 0.206 & -0.731 & 0.710 & 0.914 & 0.117 \\
\hline Estimated yearly shipments of multipurpose industrial robots & -0.296 & 0.206 & 0.260 & 0.601 & -0.091 \\
\hline \multicolumn{6}{|c|}{ Socio-economic indicators } \\
\hline Venture capital investments of GDP & -0.346 & 0.207 & -0.459 & -0.801 & 0.710 \\
\hline Employed ICT specialists & 0.120 & 0.158 & $\mathbf{0 . 8 2 0}$ & 0.190 & -0.028 \\
\hline Human resources in science and technology (HRST) & 0.388 & 0.035 & 0.053 & 0.856 & -0.410 \\
\hline
\end{tabular}

Thus, based on the data presented in Table 1 it can be concluded that the influential factors of variation on income inequality for all considered countries are: technological changes - enterprises using software solutions and socio-economic changes - venture capital investments of GDP. Specific indicators of income inequality for France and Great Britain are the individuals using the internet for ordering goods or services and human resources in science and technology. In addition, almost all considered indicators except employed ICT specialists is crucial in the study of variations in income inequality in Spain. Specific country is Germany because there is the smallest number of relevant features factors.

The next stage is adaptive adjustment of relevant technological and socio-economic indicators in the context of impact on income inequality on the base of Internet users queries in terms of Google Trends. With growing use of the Internet as an information finding tool, new data sources become vital for efficient policy-making decisions. Google Trends helps to aggregate a time series index of the volumes for specific search terms. At this stage, authors construct such variables as "Inequality" and " 4.0 Industry" based on Google search and graphically present its dynamics and characteristics of variations in Figure 1. Charts show the annual growth of queries related to "4.0 Industry" and "Inequality" and significant correlation between these indicators since 2014 . 


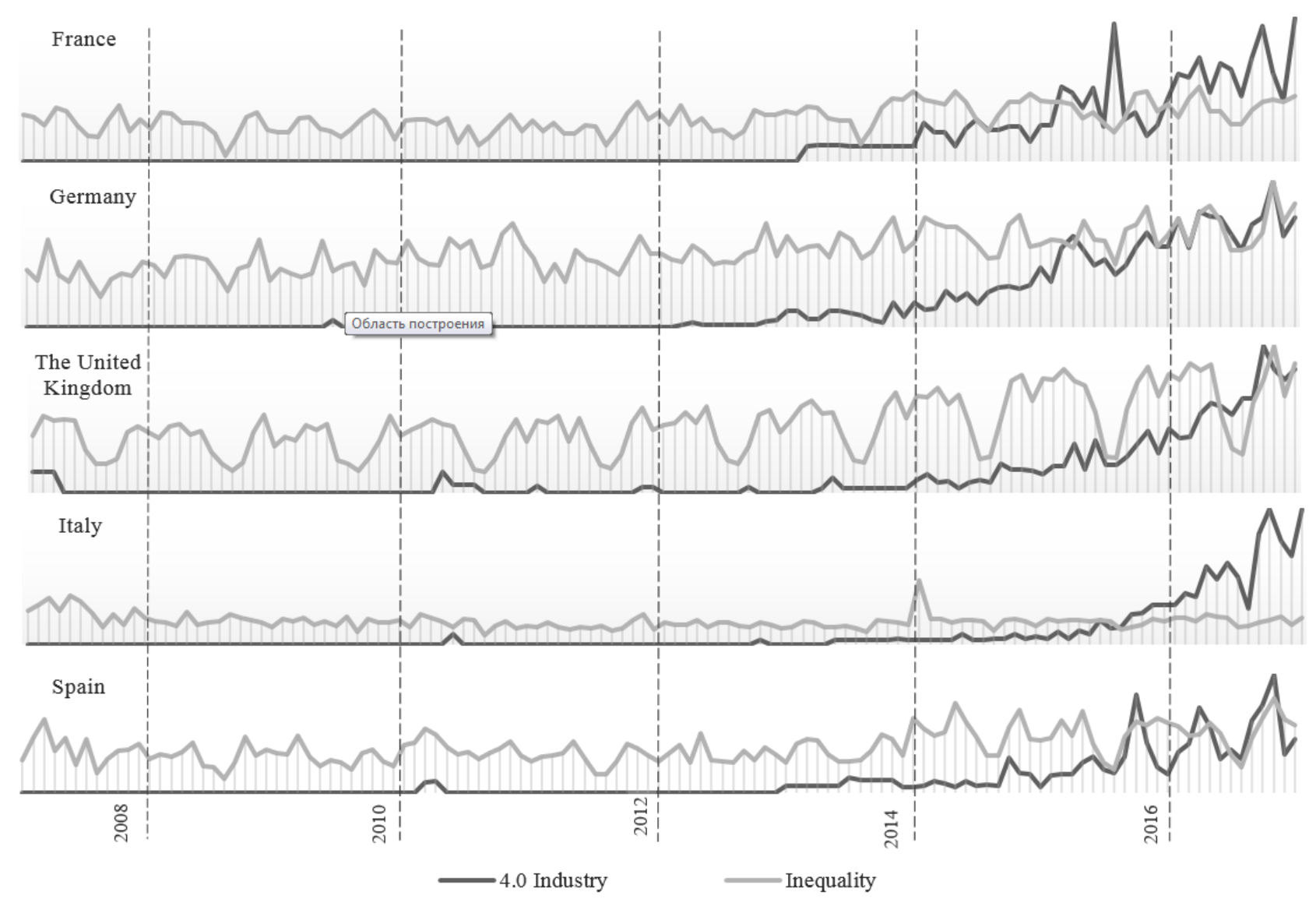

Source: authors' elaboration based on Google Trend.

Figure 1. Google Trends of "Industry 4.0" and "Inequality": select countries, 2007-2017

Secondly, the calculation of derived time series by determining the chain growth ratio, measured as the ratio of the current levels to the previous levels is performed. Thirdly, the initial relevant indicators adjustment in the context of each countries time series (technological and socio-economic indicators) by Google Trends is made. The complex transformations based on Google Trends allows to pinpoint current technological and socio-economic changes due to Industry 4.0 and implement adaptive mechanism for income inequality to current these changes. So, authors have formalized and quantified the revealed relationships between income inequality and Industry 4.0 depending on the country:

France:

$G I N I_{t}^{F}=\left(\begin{array}{l}43.3952-76.4411 \cdot \frac{I N_{t}^{G T F}}{E U S S_{t}^{F}}-67.6632 \cdot \frac{I N_{t}^{G T F}}{I U I_{t}^{F}}+3.5479 \cdot \ln V K_{t}^{F}+ \\ +191.6850 \cdot \frac{1}{H R S T_{t}^{F}}+0.6367 \cdot \sin t+0.3377 \cdot \cos t\end{array}\right) \cdot I E_{t}^{G T F}$,

where $G I N I_{t}^{F}$ - Gini coefficient at the moment of time $t$ for France;

$E U S S^{F}$ - enterprises using software solutions at the moment of time $t$ for France;

$I U I^{F}$ - individuals using the Internet for ordering goods or services at the moment of time $t$ for France;

$V K^{F}$ - venture capital investments of GDP at the moment of time $t$ for France;

$H R S T^{F}$ - human resources in science and technology (HRST) at the moment of time $t$ for France;

$I E_{t}^{G T F}$ - number of Internet requests "Industry 4.0" (Google Trends) at the moment of time $t$ for France;

$I E_{t}^{G T F}$ - number of Internet requests "Inequality" (Google Trends) at the moment of time $t$ for France. 
Germany:

$G I N I_{t}^{G}=\left(\begin{array}{l}36.7925+93.3364 \cdot \frac{I N_{t}^{G T G}}{E U S S_{t}^{G}}-4.1168 \cdot \ln S E T_{t}^{G} \cdot I N_{t}^{G T G}+ \\ +2590.4449 \cdot\left(V K_{t}^{G}\right)^{3}-0.5459 \cdot \sin t-0.3157 \cdot \cos t\end{array}\right) \cdot I E_{t}^{G T G}$,

where $G I N I_{t}^{G}-$ Gini coefficient at the moment of time $t$ for Germany;

$E U S S^{G}$ - enterprises using software solutions at the moment of time $t$ for Germany;

$S E T^{G}$ - share of enterprises' turnover on e-commerce at the moment of time $t$ for Germany;

$V K^{G}$ - venture capital investments of GDP at the moment of time $t$ for Germany;

$I N_{t}^{G T G}$ - number of Internet requests "Industry 4.0" (Google Trends) at the moment of time $t$ for Germany;

$I E_{t}^{G T G}$ - number of Internet requests "Inequality" (Google Trends) at the moment of time $t$ for Germany.

Italy:

$G I N I_{t}^{I}=\left(\begin{array}{l}26.1136-0.0122 \cdot \frac{I N_{t}^{G T I}}{E U S S_{t}^{I}}-0.0846 \cdot \cos \left(I U I_{t}^{I}\right) \cdot I N_{t}^{G T I}+ \\ +0.2862 \cdot \ln S E T_{t}^{I} \cdot I N_{t}^{G T I}+164.6606 \cdot \sin \left(V K_{t}^{I}\right)+0.0107 \cdot \frac{1}{I C T_{t}^{I}}\end{array}\right) \cdot I E_{t}^{G T I}$,

where $G I N I_{t}^{I}$ - Gini coefficient at the moment of time $t$ for Italy;

$E U S S^{I}$ - enterprises using software solutions at the moment of time $t$ for Italy;

$I U I^{I}$ - individuals using the Internet for ordering goods or services at the moment of time $t$ for Italy;

$S E T_{t}^{I}$ - share of enterprises' turnover on e-commerce at the moment of time $t$ for Italy;

$V K_{t}^{I}$ - venture capital investments of GDP at the moment of time $t$ for Italy;

$I C T_{t}^{I}$ - employed ICT specialists at the moment of time $t$ for Italy;

$I N_{t}^{G T I}$ - number of Internet requests "Industry 4.0" (Google Trends) at the moment of time $t$ for Italy;

$I E_{t}^{G T I}$ - number of Internet requests "Inequality" (Google Trends) at the moment of time $t$ for Italy.

$>$ Spain:

$G I N I_{t}^{S}=\left(\begin{array}{l}111.2107+1.5234 \cdot \cos \left(E U S S_{t}^{S}\right) \cdot I N_{t}^{G T S}-17.0293 \cdot \frac{I N_{t}^{G T S}}{E G O V_{t}^{S}}-0.0715 \cdot \cos \left(I U I_{t}^{S}\right)_{-} \\ -114.0065 \cdot \frac{I N_{t}^{G T S}}{S E T_{t}^{S}}-4317.0612 \cdot \frac{I N_{t}^{G T S}}{E I R_{t}^{S}}+88.6150 \cdot \sin \left(V K_{t}^{F}\right)-17.9129 \cdot \ln \left(H R S T_{t}^{F}\right)\end{array}\right) \cdot I E_{t}^{G T S}$,

where $G I N I_{t}^{S}-$ Gini coefficient at the moment of time $t$ for Spain;

$E U S S_{t}^{S}$ - enterprises using software solutions at the moment of time $t$ for Spain;

$E G O V^{S}$ - e-government activities of individuals via websites at the moment of time $t$ for Spain;

$I U I_{t}^{S}$-individuals using the internet for ordering goods or services at the moment of time $t$ for Spain;

$S E T_{t}^{S}$ - share of enterprises' turnover on e-commerce at the moment of time $t$ for Spain;

$E I R_{t}^{S}$ - estimated yearly shipments of multipurpose industrial robots at the moment of time $t$ for Spain;

$V K_{t}^{S}$ - venture capital investments of GDP at the moment of time $t$ for Spain;

$H_{R S T}{ }^{S}$ - human resources in science and technology (HRST) at the moment of time $t$ for Spain;

$I N_{t}^{G T S}$ - number of Internet requests "Industry 4.0" (Google Trends) at the moment of time $t$ for Spain;

$I E_{t}^{G T S}$ - number of Internet requests "Inequality" (Google Trends) at the moment of time $t$ for Spain. 
the United Kingdom:

$G I N I_{t}^{U K}=\left(\begin{array}{l}-18.5014-2.1549 \cdot \ln E U S S_{t}^{U K} \cdot I N_{t}^{G T U K}-212.4753 \cdot \frac{I N_{t}^{G T U K}}{I U I_{t}^{U K}}+ \\ +70.2454 \cdot \sin \left(V K_{t}^{U K}\right)+15.2788 \cdot \ln H R S T_{t}^{U K}-0.3144 \cdot \sin t+0.8183 \cdot \cos t\end{array}\right) \cdot I E_{t}^{G T U K}$,

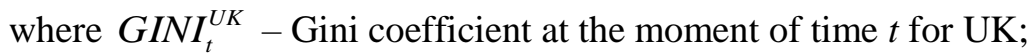

$E U S S^{U K}$ - enterprises using software solutions at the moment of time $t$ for UK;

$I U I^{U K}$ - individuals using the internet for ordering goods or services at the moment of time $t \mathrm{UK}$;

$V K^{U K}$ - venture capital investments of GDP at the moment of time $t$ for UK;

$H R S T^{U K}$ - human resources in science and technology (HRST) at the moment of time $t$ for UK;

$I N_{t}^{\text {GTUK }}$ - number of Internet requests "Industry 4.0" (Google Trends) at the moment of time $t$ for UK;

$I E_{t}^{G T U K}$ - number of Internet requests "Inequality" (Google Trends) at the moment of time $t$ for UK.

Based on identified the trend and cyclical component of the dynamics of income inequality and indicators which are characterized by technological and socio-economic changes authors nowcaste the level of Gini ratio adjusted with the Fourth Industrial Revolution growth on the base of Google Trends. At this stage the visualization of considered time series using dynamics diagrams is performed (Figure 2).

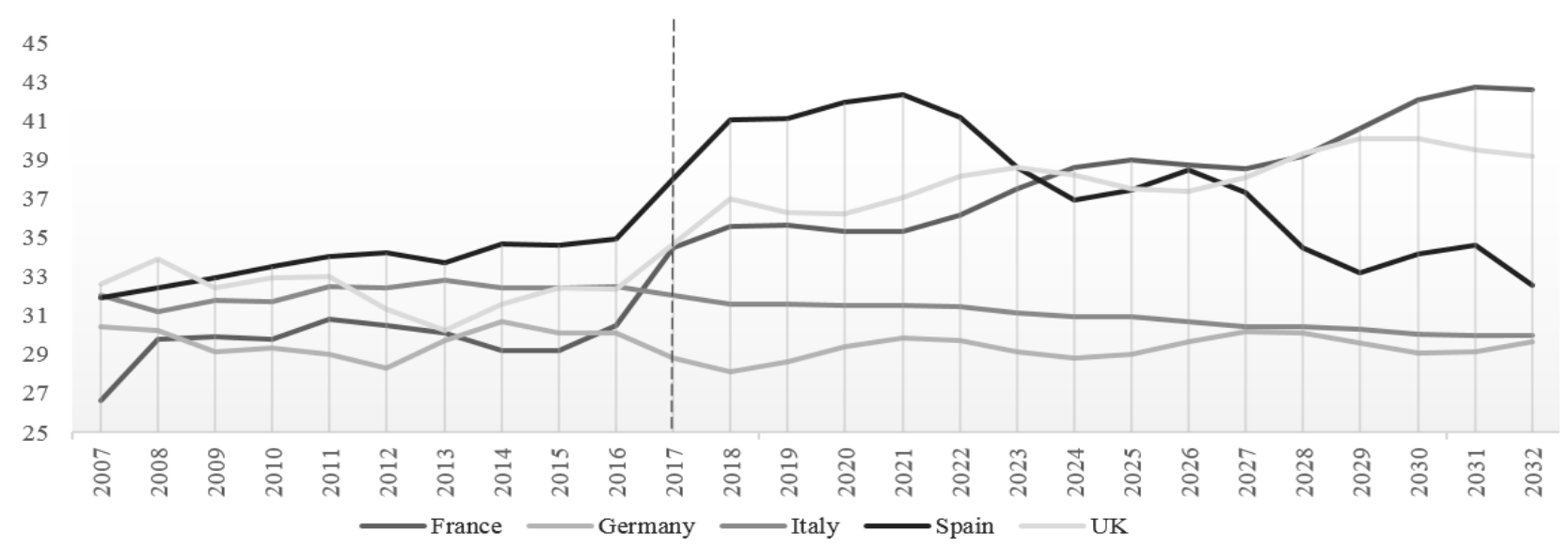

Source: authors' elaboration.

Figure 2. Gini ratio adjusted with the Fourth Industrial Revolution Growth

Forecasting results show that income inequality under the influence of the Fourth Industrial Revolution in the coming years will grow rapidly in countries such as France, the United Kingdom, Spain. As new technologies tend to complement of high-skilled workers and replace for low-skilled workers, public authorities of these counties need to pay more attention at problem solving as for income inequality through equitable access to resources and services, tax transformation and so on. Currently the Gini ratio in Germany is about $30 \%$, but in the near future there will be decrease as a result of technological shifts. The main explanation is that Germany is very advanced in the field of digitalized industry. For instance, in 2010, the German Federal Government adopted Industry 4.0 Strategy which involves a wide range of program to develop skills required for the Industry 4.0.

\section{Conclusions}

This paper has used data to nowcast income inequality adjusted with the Fourth Industrial Revolution growth in five European countries. To nowcast future level of Gini ratio, authors perform the following steps: the identification of the relevant technological and socio-economic indicators that carry on significant influence on the income inequality; data collection using Google Trend tool; recognition trend and the cyclical component of the dynamics of income inequality and Industry 4.0 indicators; nowcasting Gini ratio with the influence of the Fourth Industrial Revolution. A further contribution of this study lies in the investigation of correlation between income inequality and the Fourth Industrial Revolution in developing countries. 


\section{References}

1. Acemoglu, D. (2002). Technical Change, Inequality and the Labor Market. Journal of Economic Literature, 40(1), 7-72.

2. Barro, R.J. (2000). Inequality and Growth in a Panel of Countries. Journal of Economic Growth, 5(1), 5-32.

3. Behar, A. (2013). The Endogenous Skill Bias of Technical Change and Inequality in Developing Countries, IMF Working Paper 13/50, International Monetary Fund, Washington.

4. Berg, A., Ostry, J.D. (2011). Inequality and Unsustainable Growth: Two Sides of the Same Coin? IMF Staff Discussion Note 11/08, International Monetary Fund, Washington.

5. Berman, E., Bound, J., Grilıches, Z. (1994). Changes in the Demand for Skilled Labor within U.S. Manufacturing: Evidence from the Annual Survey of Manufactures. Quarterly Journal of Economics, 109(2), 367-397.

6. Berman, E., Bound, J., Machin, S. (1998). Implications of Skill-Biased Technological Change: International Evidence. Quarterly Journal of Economics, 113(4), 1245-1279.

7. Birdsall, N. (2007), The World Is Not Flat: Inequality and Injustice in Our Global Economy, WIDER Annual Lecture 9, UNU World Institute for Development Economics Research. Retrieved from http://cgdev.org.488elwb02.blackmesh.com/doc/commentary/speeches/Birdsall WIDERpaper.pdf.

8. Borghans, L.A., ter Weel, B. (2004). The Diffusion of Computers and the Distribution of Wages, IZA Discussion Paper 1107, Institute for the Study of Labor. Retrieved from https://www.econstor.eu/bitstream/10419/20342/1/dp1107.pdf.

9. Calderón, C., Chong, A. (2009). Labor Market Institutions and Income Inequality: An Empirical Exploration, Public Choice, 138(1), 65-81.

10. Card, D., DiNardo, J. E. (2002). Skill Biased Technological Change and Rising Wage Inequality: Some Problems and Puzzle, NBER Working Paper 8769, National Bureau of Economic Research, Cambridge, Massachusetts. Retrieved from http://davidcard.berkeley.edu/papers/skill-tech-change.pdf.

11. Claessens, S., Perotti, E. (2007). Finance and Inequality: Channels and Evidence. Journal of Comparative Economics, 35(4), 748-773.

12. Dabla-Norris, E., Kochhar, K., Suphaphiphat, N., Ricka, F., Tsounta, E. (2015). Causes and Consequences of Income Inequality: A Global Perspective, Staff Discussion Note 15/13, International Monetary Fund. Retrieved from http://www.imf.org/external/pubs/cat/longres.aspx?sk=42986.0.

13. Extreme automation and connectivity: The global, regional, and investment implications of the Fourth Industrial Revolution. (2016). UBS White Paper for the World Economic Forum. Retrieved from https://www.ubs.com/global/en/about ubs/follow ubs/highlights/davos-2016.html.

14. Fosu, A.K. (2010). Growth, Inequality and Poverty Reduction in Developing Countries: Recent Global Evidence, OECD Background Paper for the Global Development Outlook, Organisation for Economic Co-operation and Development, Paris.

15. Giannone, D., Reichlin, L., Small, D.H. (2006). Nowcasting GDP and inflation the real-time informational content of macroeconomic data releases, Working Paper 633, European Central Bank. Retrieved from https://www.ecb.europa.eu/pub/pdf/scpwps/ecbwp633.pdf?491207c32ca40dfb26f 764d8c4e71db4.

16. Giskemo, G.G. (2012). Exploring the relationship between socioeconomic inequality, political instability and economic growth. Why do we know so little? Working Paper 2, CHR. Michelsen Institute. Retrieved from https://www.cmi.no/publications/file/4379-exploring-the-relationship-between-socio-economic.pdf.

17. Goldin, C., Katz, L.F. (2008). The Race between Education and Technology. Cambridge MA: Harvard University Press.

18. Guscina, A. (2006). Effects of Globalization on Labor's Share in National Income, IMF Working Paper, International Monetary Fund. Retrieved from http://www.rrojasdatabank.info/guscina2006.pdf.

19. Hornstein, A., Krusell, P., Violante, G. L. (2005). The Effects of Technical Change on Labor Market Inequalities, CEPS Working Paper 113. Retrieved from https://www.princeton.edu/ceps/workingpapers/113krusell.pdf.

20. Humanity divided: confronting inequality in developing countries. (2013). United nations Development Programme. Retrieved from http://www.undp.org/content/dam/undp/library/Poverty\%20Reduction/ Inclusive\%20development/Humanity\%20Divided/HumanityDivided_Full-Report.pdf.

21. Krueger, A.B. (1993). How Computers have Changed the Wages Structure - evidence from microdata, 1984-1989. Quarterly Journal of Economics, 108, 33-60.

22. Krusell, P., Ohanian, L., Ríos-Rull, J.V., Violante, G.L. (2000). Capital-Skill Complementarity and Inequality: A Macroeconomic Analysis. Econometrica, 68, 1029-1054. 
23. Lansing, K.J., Markiewicz, A. (2012). Top incomes, rising inequality, and welfare, Working Paper 10, Norges Bank Research. Retrieved from .http://www.norges-bank.no/contentassets/16dd2a93e9f948fe 8c5185b7892d49b8/norges_bank_working_paper_2012_10.pdf.

24. Papageorgiou, C., Jaumotte, F., Lall, S. (2008). Rising Income Inequality: Technology, or Trade and Financial Globalization? IMF Working Paper, International Monetary Fund. Retrieved from https://www.imf.org/external/pubs/ft/wp/2008/wp08185.pdf.

25. Park, D., Shin, K. (2015). Economic Growth, Financial Development, and Income Inequality, ADB Economics Working Paper Series, Asian Development Bank. Retrieved from https://www.econstor.eu/bitstream/10419/128563/1/ewp-441.pdf.

26. Perugini, C., Hölscher, J., Collie, S. (2015). Inequality, credit and financial crises. Cambridge Journal of Economics. 40, 227-257.

27. Steelman, A., Weinderg, J.A. (2004). What's Driving Wage Inequality? The Effects of Technical Change on the Labor Market. Retrieved from https://www.richmondfed.org/media/richmondfedorg/publications/ research/annual_report/2004/pdf/article.pdf.

28. Stockhammer, E. (2013). Why have wage shares fallen? A panel analysis of the determinants of functional income distribution, Conditions of Work and Employment Series 35, International Labour Organization, Geneva.

29. The World Bank Database. Retrieved from http://data.worldbank.org/.

30. The World Robotics Statistics. Retrieved from https://ifr.org/worldrobotics/.

31. Violante, G.L. (2012). Skill-biased Technical Change, The New Palgrave Dictionary of Economics, 2nd Edition. Palgrave Macmillan. 